\title{
[v]at is going on? Local and global ideologies about Indian English
}

\author{
V I N E E T A C H A N D \\ Department of Linguistics \\ University of California, Davis \\ 1 Shields Avenue, Davis, CA 95616 \\ vchand@ucdavis.edu
}

\section{A B S T R A C T}

This article examines local and global language ideologies surrounding a particular phonetic feature in Indian English, the pronunciation of /v/ as [w]. By focusing on how local and global participants - both individuals and institutions - imagine language variation through disparate framings of "neutral" and "standard," it highlights how processes of globalization and localization are interconnected, dialogic, and symbiotic. Compared are (i) sociolinguistic constructions of Indian cartoon characters, (ii) American "accent training" institutes, (iii) Indian call center and language improvement books, (iv) American speakers' interpretations of merged IE speech, and, (v) IE speakers' attitudes about IE, "neutral," and "standard" language. The relative social capital of these populations mediates both how each constructs its respective ideology about language variation, and how these ideologies dialogically interact with each other. (Language variation, language ideologies, dialogic, standard language $)^{1}$

I N T R O D U C T I O N

Blommaert 2003 has suggested that we do not have a unified theoretical framework for approaching the sociolinguistics of globalization. However, he has proposed several necessary "building blocks" for such a framework. First, Blommaert suggests that analyses be framed in terms of specific LANGUAGE PRACTICES, and not Language abstractly. Second, he suggests that research needs to examine different levels - local and global - of sociolinguistic phenomena as INTERCONNECTED. Third, he suggests that analyses focus on LANGUAGE IDEOLOGIES. Fourth, he suggests that analyses should contextualize local and global practices in a WORLD SYSTEM, within which mediating INSTITUTIONS and INEQUALITY between "substate and superstate dynamics" form the backdrop of global flows and are necessary for interpreting the relative value of global and local ideologies. Framed by these themes, this article explores ideologies of localization and globalization 
about actual linguistic practices, by focusing on discourse about a particular structural feature, the v/w phonemic merger in Indian English (IE).

The pronunciation of $/ \mathrm{v} /$ as $[\mathrm{w}]$ (hereafter abbreviated to the $\mathrm{v} / \mathrm{w}$ merger) has become iconic as a feature of Indian English. ${ }^{2}$ As I will show, the assessed social value serves as a gatekeeping device (Blackburn 2005, Shohamy 2007) for global constructions of social authority (Bourdieu 1991), while its local ideological value stands in dialogic opposition to its global value. In order to understand the nuanced connections and negotiations between local and global ideologies about this variable, I offer four types of data: the sociolinguistic construction of Apu, an Indian cartoon character from The Simpsons ${ }^{\mathrm{TM}}$, which has reached global audiences; the focused targeting of the IE v/w merger by American and international "accent reduction" institutes; personal responses by speakers of American English (AE) to a focused listening task involving merged IE data (akin to the methods of Coupland \& Bishop 2007); and IE speakers' reflections on the value and function of IE in the local context. As I discuss this material, I will address Blommaert's (2003) notion of "interconnectedness" through the concept of the dialogic (Bakhtin 1981). I ask how these four types of language ideologies dialogically speak to, reference, or refrain from acknowledging other competing ideologies. In addition, this research addresses Blommaert's "world system" approach in two particular ways related to institutions and inequality. I draw on data from two institutions, the television industry and language training institutes, to demonstrate how this iconic feature is used to construct and selectively reify globally authoritative ideologies. To understand the social value and authority of these ideologies, I discuss the socio-historical context of IE within larger global systems. I will then demonstrate that the dialogic ideologies of IE speakers stand in contrast to the lack of dialogic discourse by global and local institutions and AE speakers, precisely because of their relative global social authority.

This article is organized as follows. First, I discuss how language variation in the context of globalization has been approached thus far, which provides critical scaffolding for the analysis offered here. Next, I discuss the v/w merger and establish how the merger is a global icon for IE through its targeting by international institutions. I explore how an IE persona is discursively constructed by AE listeners who hear the v/w merger, demonstrating how fully the "other" is constructed from a single iconic feature, and how individual assessments are framed within ideologies of nativeness and standard language (Silverstein 1996, Shuck 2004). Finally, I discuss the local IE context, exploring how internally constructed IE discourse is framed in opposition to and dialogically responds to global sociolinguistic assessments.

\section{Theorizing the sociolinguistics of globalization}

Globalization, a process wherein "activities in one part of the world come to have significant consequences for individuals and communities in quite distant parts of 
the globe" (McGrew 1992:23, cited in Meyerhoff \& Niedzielski 2003), has strong implications for understanding the relationship among language structure, authority, and social capital. The study of globalization is about how situated practices connect to worldwide practices, processes, and norms, in which practices are commodified, and identities are created and (re)aligned. However, global social authority is relative and unequal (Blommaert 2003, Shohamy 2007); the valuing of particular practices and communities hinges upon the devaluing of OTHER practices and communities. This unequal power relationship leads many people to expect that the world will become homogeneous, with practices of low social value abandoned in favor of globally prestigious practices. However, it is not that simple. Practices can have multiple values simultaneously, depending on whether one examines the local or the global. Processes of globalization are integrally linked to processes of localization, whereby differences in practices emerge or are reevaluated for local social capital. Indeed, globalization and localization are not simply two interrelated aspects of a larger process; I argue here that they are symbiotic and dialogic (Bakhtin 1981).

Globalization can also be considered syncretic. That is, through globalized connections, repertoires of practices grow, awareness of global and local practices grows, and additional global identities are interwoven with preexisting local identities: There is an accumulation of previously separate practices and identities. For example, speakers do not lose their local or national identity and relative social capital, but they can and do gain (or have imposed upon them) a globalized identity and globally relative social capital, through their interactions with global practices and alignments (Erling 2007, Dendrinos, Karavanta \& Mitsikopoulou 2008). One important way similarity and difference are globally constructed is through language practices. Fundamental to this is the theoretical assumption that language practices do more than convey and reflect linguistic meaning; they articulate social difference and similarity. The sociolinguistics of globalization as a research agenda focuses on the social evaluation and transformation of language practices in global economies, wherein language practices are used to instantiate and negotiate relations of social power and authority in global and local settings.

How does this work? Speakers treat discrete practices as part of larger collections of shared cultural practices, in which some become iconic, indexing larger sets of practices. However, language practices are also associated with ideologically and socially constructed dichotomies of "us" versus "other." Language ideologies encapsulate, describe, and explain individual and social understandings of how language organizes and constitutes social alignments (Woolard 1998). "Publicly circulated language ideologies shape the layperson's experience of language. These belief systems, which often reinforce the dominance of a standard, provide a (if not the) lens through which speakers interpret and understand the language variation that they encounter" (Wassink \& Curzan 2004:175), and influence the global commodification of language variation. The sociolinguistics of globalization 
is thus focused on how language variation is constructed as social difference and unequally commodified.

Language ideologies are articulated through several discursive modes - media, language classrooms and training centers, and government policy - and by local and transnational speakers assessing language practices. Importantly, globalized ideologies about particular language practices are constructed by at least two communities with disparate relative global social capital: those targeted by such entailments - here, local IE speakers - and those whose speech is in contrast, and doesn't reflect these practices, here global "standard" language speakers. Because local identities and authority exist in conjunction with globalized ones, tension can arise between the local and global social capital of language practices. I examine differences in the social value offered to particular language practices through a comparison of localized and globalized ideological constructions.

Past research has dominantly focused on EITHER globalized or localized ideological discourse and/or practices as they interact with larger processes of globalization and social (re)evaluation. Addressing the former, a global identity that individuals are encouraged to adopt and align with is constructed and negotiated through globalizing discourse in international glamour magazines (Machin \& van Leeuwen 2003) and travel media (Thurlow \& Jaworski 2003); globalizing economic and political discourses are argued to negatively affect local norms and ideologies (Fairclough 2006); and global languages in the context of powerful national languages provoke further marginalization of minority language speakers (Shohamy 2007). Addressing the last, local language practices are adopted or reevaluated to index more valuable global identities in various ethnic and minoritized settings (Rampton 1995, Heller 2003, Shankar 2004, Pennycook 2007), English codeswitching is used in advertisements to construct modern local consumers (J. S. Lee 2006), and English proficiency mediates German/English bilinguals' re-creation of local, national, European, and global identities (Erling 2007). Problematizing linguists' assumptions of which language features are actually the result of globalization, Meyerhoff \& Niedzielski 2003 highlight how locals separate some purportedly imported features and contrastively consider them local. Focusing on local reactions to the social and economic investment in global standards, the imposition of British and American language practices in call centers is problematized as degrading to local Indian and Pakistani norms (Cowie 2007, Rahman 2009). Meanwhile, ideologies about local, regional, ethnic, and international English dialects demonstrate both pervasive prescriptivism as a means of evaluating speakers, and gradual destigmatization by youths and women, suggesting potential changes in processes of evaluation, potentially linked to globalization (Coupland \& Bishop 2007). There is also much research on local language practices serving local and translocal identity needs, which we cannot explore here for lack of space. Missing from past research are focused syntheses of local and global processes of ideological construction of language practices, which can serve both to critique and to understand how ideologies are constructed by 
individuals and media interested in either opposing or accommodating processes of globalization. Analyses of the linkages between discrete language practices and both local and global evaluations are critical for understanding the interweaving of globalization with localization.

THE I E V/W PHENOMEN ON

Indian English is an umbrella term for multiple English varieties spoken in India by speakers of varying fluency, nativity, ethnic, regional, and linguistic backgrounds (Kachru 1983, Sahgal \& Agnihotri 1988, Baumgardner 1996, Coelho 1997). Within this, the $\mathrm{v} / \mathrm{w}$ phenomenon has been broadly labeled as a pan-IE feature (Trudgill \& Hannah 2002). The merger entails a "loss" of the fricative phoneme so that both $/ \mathrm{w} /$ and $/ \mathrm{v} /$ are realized as labial approximants (Sahgal \& Agnihotri 1988, V. Chand 2007). Meanwhile, several regionally focused papers have narrowed the population of v/w-merging IE speakers into regionally distinct varieties of IE (e.g., Chaturvedi 1973, Agnihotri \& Sahgal 1985), across which $\mathrm{v} / \mathrm{w}$ merging is not consistent.

The v/w merger may have evolved through substratum contact (several Indian languages have a $\mathrm{v} / \mathrm{w}$ phonemic merger) or it may have developed from colonially introduced English practices (Trudgill, Schreier, Long \& Williams 2004). However, regardless of its phonemic details or developmental path, the merger is globally understood as a non-native feature, wherein native and non-native IE speakers are conflated in terms of fluency, competence, and nativity.

I D E O L O G I E S

The monoglot standard ideology (Silverstein 1996) interprets dialects as being unequal, with a single "standard" and multiple "nonstandard" dialects. In conjunction with this, Shuck postulates an "IDEOLOGY OF NATIVENESS, that constructs the category 'native English speakers' as contiguous with Americans (and sometimes British), and 'non-native English speakers' as contiguous with foreigners" (2004:196). Accents are regarded as incomprehensible, and in standard language contexts, complaints about immigrants "who do not learn "the language"" (Shuck 2004:196) are common. Here a direct ideological link exists between "foreigners," "nonstandard" speech, and unintelligibility.

This hegemonic ideology is intertwined with sociolinguistic conceptualizations of "us" versus "others," (un)intelligibility, and commodification of a "standard" (Silverstein 1996, Blommaert 2003). Dominant ideologies are naturalized and reified through speakers' interactions with in-group members versus others, as "semiotic movements of interpretation and construal ... operate ... in the ongoing processes of production and comprehension of our own and of others' social behavior" (Silverstein 1996:295). These processes create and perpetuate a particular 
social reality, working as a form of erasure (Gal \& Irvine 1995), where linguistic differences are forgotten or made secondary, and presumed social differences (e.g., aptitude, education, and intelligence) are fronted as explanations for linguistic variation. "Through such naturalization, extralinguistic properties or attitudes of individuals can be read in and from their participation in standardization ... processes" (Silverstein 1996:290). Language variation must be interpreted within this social understanding of language power and standard language ideology, so as not simply to construe linguistic diversity as ideologically neutral. As well, we must heed processes of globalization, wherein language structures are globally (re)commodified, and their speakers gain or lose global social authority.

The theoretical framework presented here permits analysis of the dialogic process of language commodification between global and local communities. AE speakers are modern-day prototypical torch-bearers of "standard" language practices and ideologies in the current globalized context (Silverstein 1996, L. Milroy 2000, Meyerhoff \& Niedzielski 2003). AE institutional depictions of IE speech thus inform our understanding of globalized stereotypes surrounding the structure of IE in a "standard English" (Silverstein 1996) context, as speakers "perceive variation in the speech of others and ... use it to structure our knowledge about that person" (Lippi-Green 1997:30).

\section{Cartoon constructions of IE}

By far the most (in)famous Indian voice in the media is Apu, a fictional cartoon Simpsons ${ }^{\mathrm{TM}}$ character, who is a South Indian immigrant, ${ }^{3}$ voiced by Hank Azaria, a native-born American. Azaria adopted Apu's style of speaking from an amalgamation of Indian and Pakistani convenience store owners in the Los Angeles region (Azaria 2004). Apu's speech is characterized by grammatical errors, stopped fricatives, the $\mathrm{v} / \mathrm{w}$ merger, and statements that mark him as a buffoon, akin to the link Chelliah 2006 uncovered between IE features and "buffoonery" in fiction writing. Completing the caricature, Apu, a convenience store proprietor in the series, is highly overqualified, holding a Ph.D. in computer science.

Apu is portrayed through social and linguistic practices as unintelligible and non-fluent. Addressing intelligibility, one website, showcasing audio clips of each character's speech, provides an audio file with Apu saying "Please do not offer my god a peanut," while the transcript of this audio file reads "Please do not feed my god a peanut" (Lee 2008). Apu, in another episode and in what has become a classic Apu quote, pronounces silly as 'killy', reinforcing the idea that IE speech is riddled with errors - ones that inhibit intelligibility - and highlighting the stopping of fricatives, an IE feature (cf. Kachru 1982:359). Apu himself capitalizes on the belief that IE speakers aren't fluent in English; one could say that he dialogically exploits this ideology by denouncing his English fluency and competency IN English while a generic American customer challenges this assertion: 
(1)

Apu: Yes, I'm sorry, I do not speak English, OK.

Customer: But you were just talking -

Apu: Yes, yes, hot dog, hot dog, yes sir, no sir, maybe, OK.

IE is further characterized as having "excessive" politeness (Labru 1984:57), clearly evident in Apu's speech, given his catch phrase "thank you for coming" in extreme situations of insulting someone ("Thank you for coming, I'll see you in hell") or confronting shoplifters ("Please pay for your purchases and get out and come again"). Indexing Indian areal echo-word constructions (Abbi 1980, Emeneau 1980 [1956]:114), Apu also uses rhyming words: "Hands off my jerky, turkey."

Apu indexes the $\mathrm{v} / \mathrm{w}$ merger through his [v]-like pronunciation of some target /w/s: In a greeting to Kwik-E-Mart customers, he says "hello gents, what will it be," but this /w/ does not evidence formant structure, and perceptually sounds like a fricated $[\mathrm{v}]$, resulting in $[\mathrm{vh}] \mathrm{at}$. Ironically, this [v]-like pronunciation of target $/ \mathrm{w} /$ is the OPPOSITE of IE speakers' actual pronunciation: The v/w merger is characterized as a loss of the fricative phoneme, with both realized as labial approximants (Chaturvedi 1973, Sahgal \& Agnihotri 1988). Thus, this imitation IE speech does not distinguish /v/ and /w/: Apu's pronunciation is separated from "standard" English by acoustically merging /v/ and /w/.

Apu illuminates several AE pop-understandings of IE speech: unintelligibility (even to serious Simpsons fans, demonstrated by mistranscribed quotes on fan websites), grammatical errors, stopped fricatives, and the $\mathrm{v} / \mathrm{w}$ merger. Apu is socially constructed, and his depiction metaphorically represents and re-presents all IE speakers to a global audience. These depictions tell us, the audience, that IE speakers are unintelligible, non-fluent English speakers, overly polite, unsavvy businessmen, and that they have specific, easily identifiable linguistic idiosyncrasies. Simpsons viewers are encouraged, through the concentrated use of particular linguistic and social practices, to forge a link between the two.

\section{IE accent training}

The global "liabilities" and pejorative links associated with IE are made salient through U.S.-based newspaper articles and company business plans. One news report about Indian call centers targets Indian workers as the locus of unintelligibility in two-way AE/IE interactions: "Call centers in India might help U.S. companies cut costs, but there are no guarantees of the quality of service, especially with the way English is spoken by some Indians - WITH ACCENTS AND HARSH CONSONANTS THAT CAN MAKE THEIR CONVERSATIONS INCOMPREHENSIBLE TO U.S. CALLERS' (Mahapatra 2006, emphasis mine). "Good service" is thus constructed as intelligible, non-accented speech, and accents are located as speech that diverges from AE. Further, the burden of intelligibility is placed squarely on 
the IE speakers' shoulders; they are targeted as nonstandard. IE speakers have minimal social authority for determining intelligibility and standard on a global scale, while AE speakers marshal considerable authority, realized through individual attitudes and prescriptive institutions like accent training centers. AE speakers' social authority is rooted in monoglot standard language ideology: "Standard' English speakers speak 'good' English" (Silverstein 1996). "Virtually everyone subscribes to the ideology of the standard language, and one aspect of this is a firm belief in correctness ... when there are two or more variants of some word or construction, ONLY ONE OF THEM CAN BE RIGHT' (J. Milroy 2001:534-35, emphasis mine). Speakers from nonstandard dialects are judged against ideologically enforced and constantly reified norms, and structural differences (e.g., language variation) are understood as errors that cause miscommunications and poor service.

In conjunction, many Americans are upset over the migration of jobs to India (e.g., as reported by Dudley 2004, McPhate 2005, and Mahapatra 2006), resulting in a backlash against Indian workers:

Many Indian call-center workers say they regularly face particular abuse from Americans, whose tantrums are sometimes racist and often inspired by anger over outsourcing ... Callers often dismiss them the moment they detect their Indian accents. (McPhate 2005)

Targeting this problem, various types of accent-reduction training courses exist and are highly popular for individuals and businesses referring employees. While these course all focus on explicit language training, they often include classes on American culture:

The Tucker Program gives them a cultural framework to build on and teaches them to communicate the way Americans do. It provides them with an understanding of American cultural values and where they came from, contrasts differences among regions of the U.S., focuses on recent trends and American lifestyles, and teaches them to deal effectively with American customer attitudes and expectations. (Tucker International 2004)

Cultural familiarity and at least partial cultural assimilation are therefore incorporated within accent training.

Their eye on explicit language training is clear: One company focused toward working with Fortune 500 companies offers "proven techniques to quickly master English PRONUNCIATION" (Accent Reduction Institute 2008, emphasis mine). Indeed, a quick glance at the "problems" they claim to solve highlights that, from their perspective, the issue with such accents is particularly phonetic and phonological in nature. The $\mathrm{v} / \mathrm{w}$ merger is represented to the global community as a fixable error. Hinging on the existence of standard English, the courses come with extensive sales pitches touting the benefits of speaking in standard English and the need for cultural training, within this. Their understanding of accents sheds light 
on the relationship they perceive, and that they encourage their customers to perceive, among accents, intelligibility and business interactions, and the repercussions of a "heavy" accent:

Heavy accents hurt sales and profitability, create language barriers and miscommunications, lower confidence and a person's ability to contribute, cause inefficiency, interfere with communication at tradeshows and presentations, prevent effective teamwork, frustrate customers, prevent salary increases, promotions, and raises. (Accent Reduction Institute 2008)

These courses specifically target the IE v/w phenomenon. One course describes IE-specific training wherein "Hindi speakers practice saying 'available' instead of 'awailable"" (Gorman 2007). Interestingly, these institutes do not acknowledge their customers as potential native English speakers - albeit of a different variety of English; they do not say "English speakers from India" or "ESL speakers," for example. Instead, they assess all Indians as non-native, labeling them "Hindi speakers," itself a gross oversimplification. By ignoring the possibility of native IE speakers, they themselves enact and reify the ideology of nativeness, wherein any accent other than American (or sometimes British) is considered non-native. "Accents" are used as a gatekeeping device (Blackburn 2005, Shohamy 2007) in the attribution of global social authority, and, here, professional competence. Accents are bad for business, interfere with communication, and hinder personal success. Accent reduction is also important for internal evaluations of self-worth: "By working with The Accent Reduction Institute, clients raise their self-confidence" (Accent Reduction Institute 2008). These companies are prime examples of how standard language ideology is institutionalized in a global context.

\section{AE evaluations of merged IE speech}

Given these globalized, media-imposed ideologies, we will now examine how individual AE speakers respond to IE speech - the v/w merger in particular - and whether they index institutional(ized) ideologies. A total of 127 individual evaluations of merged IE speech was captured within a larger perceptual test presented to AE speakers (V. Chand 2007). These speakers, Californian students and consumers, have had a range of experiences interacting with IE speech through school, media (e.g., The Simpsons), call center interactions, and in their communities, given the large Indian diaspora population of California.

Respondents first listened to AE and IE pronunciations of 10 words ${ }^{4}$ containing $/ \mathrm{v} /$ and $/ \mathrm{w} /$. Both speech samples were naturally produced and acoustically verified to ensure that they matched norms for their respective dialect structures: The AE examples had fricated /v/s and approximated /w/s, while the IE examples reflected a continuum of [v] to [w] articulations for words with either /v/ or /w/ "targets." Respondents transcribed what they heard and assessed both speakers in two ways. Each speaker's personality was evaluated through ten traits on a 5-point 
Likert scale (e.g., unfriendly...friendly, insincere... sincere, impolite...polite), using methods very similar to those of Coupland \& Bishop 2007. They also completed a free response section about their reflections on the two speakers. These free response reflections are examined here, while the results of the categorization and quantitative assessments have been discussed elsewhere (V. Chand 2007).

Several themes arose in these responses concerning articulation, $\mathrm{AE}$ as a neutral accent, English nativity, nonlinguistic traits, and professional aptitude. While some participants recognized the ideological link speakers forge between comprehension and assessment (e.g., "I would say that when I have difficulty understanding someone, I judge them as less likeable and competent overall" (AEfirst R40) ${ }^{5}$ ), the majority of participants instead evoked standard and native language ideologies (Silverstein 1996, Shuck 2004). First, the IE speaker's language was targeted as failing to articulate "correctly" or clearly:

The speaker (IE) didn't say some of the words clearly (IEfirst R78). She (IE) had an accent and did not annunciate (sic) and articulate as clearly as the 2nd speaker (AE) (IEfirst R11). The 1st speaker (IE) lacked the ability to produce more sounds than speaker 2 (AE) (IEfirst R60). Speaker A (IE) enunciated less than Speaker B (AE) (IEfirst R66). I think speaker A (AE) pronounced their words more effectively (AEfirst R11). She (IE) had a very thick accent. She had trouble with the uh, w, and v sounds (AEfirst R44).

The $\mathrm{v} / \mathrm{w}$ merger is clearly salient to listeners and was consistently highlighted as a "problem."

Depicting the IE speaker as "lacking the ability" or having "trouble" indexes standard language ideology, wherein there is a standard (in this case, $\mathrm{AE})$, and those who talk differently do not meet this standard. Indeed, the AE accent is constructed as the neutral standard: "Speaker B (AE) ... had a more neutral accent, A (IE) sounded Indian" (IE first R62). Evoking foreignness, as this quote does, establishes the IE speaker as a non-native English speaker, the next entailment in the ideology of nativeness. Many participants located the IE speaker as foreign, with a "heavy" accent, and in particular, as Indian: "I think speaker A (IE) had an Indian accent, making her harder to understand" (IEfirst R5). Supporting this judgment, in several other instances the IE speaker was not directly identified as foreign, but instead identified as hesitant or insecure, with her speech labeled more effortful because of an assumed lack of fluency:

The second speaker (IE) was hesitant in her tone and manner (AEfirst R19). I feel that Speaker A (IE) was trying really hard to say words that the speaker didn't know. Speaker B (AE) knows a little better language than that of Speaker A (IE) (IEfirst R75). She (IE) seems insincere about what she is saying because she is not exactly sure if that's the way to be pronouncing the word (IEfirst R5). 
Meanwhile, the IE speaker's fluency and nativity were directly highlighted to explain her "poor" speech:

Speaker A (IE) sounded as if she was from a different country and just learning to speak English. Speaker B (AE) sounded English proficient (IEfirst R49). The first speaker (IE) was difficult to understand and seemed to be still in the learning stage of English speaker (IEfirst R70). I can tell that speaker A (AE) is an English native, while speaker B (IE) is speaking it as a second language (AE first R9). Speaker B (IE) had more of an accent and she didn't sound like English was her native language (AEfirst R45).

This process of first establishing the IE speaker as non-native, then attributing supposed communicative deficiencies to the IE speakers' non-native and nonfluent status, shifts the burden of intelligibility and comprehension away from the listener, and can be understood as reflecting a discourse of exclusion (Shuck 2004) that reflects unequal global social authority.

Once speakers are considered non-native, non-fluent, and unintelligible, the final link is made, wherein linguistic traits are no longer salient - they are erased (Gal \& Irvine 1995) - and the IE speaker's personality is used to "explain" her language practices:

The first speaker (IE) was very cheerless ... and doesn't like the English language (IEfirst R10). I felt that the first speaker (IE) was particularly unfriendly sounding and difficult to understand (IEfirst R11). Speaker A (IE) ... I disliked the tone of her voice (IEfirst R52). Her (IE) tone seemed a lot more dismal. (IEfirst R66). Speaker A (AE) was better than Speaker B (IE) (AEfirst R18).

No similar set of negative personal evaluations framed the AE speaker; the vast majority of reflections were about the IE speaker and referenced the AE speaker only as a point of contrast, as "easier," "clearer," and "better." Finally, direct links were made to the IE speaker's projected profession, locating her as a deskbound employee, as one you might interact with because of outsourcing, but not rely on:

Speaking with outsourced tech support has taught me a little about interpreting strong accents. (IE first R2). Speaker A (IE) I visioned [sic] as being a middle-aged Indian woman sitting behind a desk (IEfirst R80). I think speaker A (IE) had an Indian accent, making her harder to understand. Thus less reliable (IEfirst R5).

Also, the speaker was identified as one who will not succeed, because, in the ideology of nativeness, "standard" language speakers do not want to interact with people who have accents and are unclear:

Some words were said unclearly by the first speaker (IE) because of her accent, which in the modern world, can be seen as a signal of unreliability - if you can't understand the person, they're hard to work with, etc. (IE first R81). If I 
needed information about something, I would have chosen the first speaker (AE) (AE first R17).

The global social authority of AE speakers in relation to IE speakers is important for understanding $\mathrm{AE}$ interpretations of language variation. Clearly, $\mathrm{AE}$ speakers do recognize links between particular language practices and communities of speakers. However, they do not simply interpret speech as "different"; that is, language variation is not just language variation. Instead, variation is compared to a standard, within which IE is found lacking. The AE listeners' social authority, as native speakers of a standard, allows them to then interpret the Other through a succession of pejorative traits linked through the ideology of nativeness. Importantly, IE speakers are not universally non-native English speakers who have failed to acquire English, as these reflections portray them; there is a growing population of native English speakers in India for whom this merger is common (V. Chand 2009). The written assessments of the IE speaker, made by AE listeners and based solely on ten words spoken in isolation, demonstrate how AE listeners faced with "different" speech locate and contextualize it with respect to dominant ideologies in very specific ways. Listeners traverse the ideologies of nativeness and standard language, referencing linguistic traits, highlighting foreignness and non-nativeness, to (re)construct global statements about the IE speaker's personality, her occupation, and how successful she will be in the modern globalized world; and these responses reflect how the global assesses the local. The pervasiveness of such stereotypes, and the ease with which these AE speakers did evoke such complete ideological constructions of the Other to "explain" language variation, are inherently contingent upon preexisting global linguistic capital and social authority. IE does not hold the power, authority, or prestige that $\mathrm{AE}$ does, and that $\mathrm{AE}$ speakers thus embody. These assessment data illustrate how globalized language ideologies interact to interpret and construct notions of fluency, nativity, competence, and individual speakerhood, which are imposed upon local communities of speakers with less global social authority.

We see, now, that global institutional and individual ideologies are pushing IE to be(come) more "accent-neutral" and more internationally intelligible - to adhere more closely to outside "standard language" norms. Further, the v/w merger in particular is targeted in global discourse as an instance of "incorrectness" or "unintelligibility" requiring remedial English training, and its presence easily evokes complex evaluations of IE speakers within a global social authority framework. However, this is only one side of the coin. In the next section I explore how language practices and relative social authority are negotiated and commodified in the local Indian context. This first necessitates explaining and historically situating English practices in India.

\section{Historically situating English in India}

Indian economic self-reliance first gained national momentum with Mahatma Gandhi and was enacted in government policies in 1947, after India gained its independence from Great Britain. Until then, English was the language of the 
government, spoken by a powerful but small minority of the population. While it would have been convenient for the newly formed Indian government to continue using English, this was not without a myriad of problems, most of which surrounded the identity of India as a collective whole and as a newly formed nationstate (T. Chand 1944). Starting in 1950, there was a 15 -year planned move from English to Hindi as India's national language. In 1963, however, the Indian government recognized that issues of national identity and linguistic and ethnic diversity could not be reconciled with Hindi as the sole national language. At that point, 15 languages were chosen, which have now expanded to 22 constitutionally recognized Dravidian and Indo-European languages. English, meanwhile, is the co-official language of the Indian Union.

Starting in the early 1990s and continuing today, a gradual loosening of India's economic borders has occurred through a growing demand for the export of skilled labor service and economic policy reforms (Gordon \& Gupta 2004). These policies have been motivated in large part through the late 1990s by increased wage remittance from Indians working in the Persian Gulf nations (Migration Dialogue 2005), and in the early 2000s by increased outsourcing and IT industries in India (Gordon \& Gupta 2004). As of 2004, India's GDP accorded with those of average lower-middleincome countries, not low-income countries. In 2006, India's economy was the third largest worldwide - in terms of GDP, second only to the United States and China (World Bank 2006). By 2010, if the 1996-2000 growth pattern continues, estimates suggest that India's services sector will be "closer to that of an upper middle income country, even though India would still belong to the low income group" (Gordon \& Gupta 2004:7). Thus, while India is still globally framed as "third world," this is not the reality that many urban IE-speaking professionals experience. With these economic and policy changes in India and the currently evolving value of IE, as an English variety in globalized commerce, an increased awareness of globally prestigious norms and standard language ideologies is being locally negotiated.

One cannot ignore processes of localization within the complexities of Indian globalization, wherein speakers identify IE as a commodity indexing an increasingly valuable local social identity. The local social identity and authority of these IE speakers can be understood as a force driving the local commodification of IE traits. Indeed, India's increased wealth has provoked internally focused political changes: In 2004, the pro-globalization Bharatiya Janata Party (BJP, Indian People's Party) was displaced as a parliamentary leader by the Congress Party, "an alliance of socialist parties that has been fiercely critical of corporate globalization" (Nichols 2004).

There is evidence from several corners that modern Indian urban culture(s) has/have developed: Speakers now identify as "Indian" over narrower ethnolinguistic, religious, and regional identities (Raj 2003). Urban Indians are increasingly using English in more intimate domains, like family and friendship (Sahgal 1991). With these types of sociopolitical changes can come internal valorization of IE and specific IE features indexing a modern urban Indian identity. For 
example, increasingly common in popular Indian literature are rejections of an outside standard and support for IE as locally relevant, as one Indian author and former UN diplomat writes:

After our chhota-pegs we sign chit-books; the next day we don our dhotis and Ghandi-topis and do pranam when felicitating the PM at his daily darshan ... As far as I'm concerned, Indianenglish Zindabad! (Tharoor 2007)

Zindabad is an Urdu term expressing accolade, enthusiasm, and approval, in this case for IE. However, IE speakers are not immune to global ideologies; comparing IE institutional and individual discourse illuminates tension between how local and global ideologies are locally negotiated.

\section{Indian institutional ideologies}

Indian media offer numerous examples calling for "improved" English in India. There are myriad IE books for popular consumption that denigrate IE (e.g., Krishnaswamy \& Burde 1998, John 2007), beyond the seemingly endless assortment of grammar books aimed to improve IE speakers' English toward outside standards (e.g., Vaid 1977, 1982). These books are not for English beginners, seeking instead to "correct" local forms: Through diligent study readers will learn "what words to use or omit to avoid the common mistakes - which are called 'Indianisms"' (Vaid 1977:7-8). Books of this type explicitly promote a variety of English intelligible (and "correct") in international contexts, for "whoever strives at making some progress in life" (Vaid 1977:7). While they typically focus on lexicon and syntax, several specifically target the v/w merger as an Indianism requiring correction. The massive economic investment in global ideologies - "Newsweek estimates that the English teaching industry in India alone is at an annual \$100 million" (John 2007:73) - suggests a continued investment in IE's "incorrect" status.

Mahapatra's newspaper article, highlighted earlier to demonstrate judgments of the IE accent as "harsh" and responsible for misunderstandings, is similarly written by an Indian, for an Indian audience, and promotes accent training with an emphasis to "help people speak English in an accent-neutral manner" (2006). Implicit in such a suggestion is that IE is NOT "neutral." In short, Indian media offer no local value for IE, and they do not dialogically respond to individual attributions of local authority and authenticity through IE practices. Notions of IE as non-neutral, unintelligible, and incorrect are absorbed by local institutions, and are now wielded by IE speakers against other IE speakers.

Examining the notion of "accent-neutral" more closely, in Indian and Pakistani call centers workers must complete accent training courses to adapt their English toward American or British norms before they begin taking calls (Cowie 2007, Rahman 2009). This training has two motivations: first, to disguise the origins of the call center worker by disguising their local accent - that is, to "pass" (Rampton 1999) as American or British to the customer. This is done to reduce hostility 
directed toward workers, who, if their actual identity were known, would be exposed to more vocal (if misplaced) resentment from AE customers (Dudley 2004, Cowie 2007, Rahman 2009). For example, accents provoke extreme agitation in call center interactions:

Partho let his accent slip and had to confess after being pointedly questioned that he was, in fact, an Indian sitting next to a telephone in Mumbai. 'The man told me, "You guys blew up the WTC.", (Joseph 2002)

Second, these courses are expected to cultivate a "neutral international accent." However, the results of such a process of neutralization are unclear, and have been controversially linked to incorporating some British or American features, achieving a near-native standard American accent, or contrastively, eliminating stigmatized local features (Cowie 2007, Rahman 2009). This type of conflict between intended and actual goals is also found in Pakistani call center training. Stated goals are often framed as in this comment:

"We call this a class in accent neutralization and not one in teaching American accent. What we do is to neutralize the strong Pakistani accent so that it becomes neutral. Like when you use it the other guy wonders: 'Where is he from? Where is he from? But he isn't a foreigner!' So there is no accent; no foreign touch." (Rahman 2009)

In actuality, however, these courses encourage replacing Pakistani phonology and intonation with AE patterns. The definition of "neutral" is thus unclear, but, importantly, the "lack of phonemic distinction between /v/ and /w/" was itself targeted in call center training as a pan-Indian feature (Cowie 2007:319).

Locally produced institutional ideologies about IE thus target the v/w merger as a nonstandard, devalued, and specifically Indian feature. They reference the same standard and native language ideologies present in international media and AE reflections. However, beyond essays of the sort offered by Tharoor 2007, which talk ABOUT IE, also emerging are novels that USE IE to index local Indian authenticity. While IE features are used to construct and voice "buffoons and villains" (Chelliah 2006), there are also Indian novels that dialogically challenge these negative evaluations, and instead use IE features to evoke a socially and contextually authentic Indian persona. In particular, the v/w merger is uncovered as a device for locating characters as "real" Indians whose actions and motivations must be interpreted within Indian - not global - norms and customs. For example, in Londonstani, the merger is used to assert adherence to Indian - not British - customs:

Vot kind of man you are? Where our invitation is? Lost in bloody post? Vhy we not invited? ... Don't give me stupid question. Their daughter is becoming our daughter and you give me stupid question. Vot kind of man you are? And today my friends ask me vot I'm wearing on Saturday. Wearing to vot? How shameful this is. (Malkani 2006:241) 
The v/w merger is readily apparent and is selectively used by a mother (and, underlyingly, the author) when she faces conflict between British and Indian marriage customs: Using the merger establishes her as interpreting circumstances through a local Indian frame. However, there is a clear difference in the reach and power of a few authors' valorization and/or use of IE features through fiction, as compared to the institutionally sanctioned ideologies offered through educational materials and the call center industry. This begs the question of which ideological framework individual IE speakers attend to, and how they dialogically respond to global and local institutional language ideologies. To these we now turn.

\section{Local IE speaker ideologies}

In 2007-2008 I conducted sociolinguistic interviews with 35 upper-middle-class Hindi/English early bilinguals in South Delhi, India, aged 18 to 87 . These data were collected with two dominant goals: first, to collect extended naturalistic oral IE data for quantitative analysis (V. Chand in preparation), and second, to elicit speakers' linguistic attitudes, personal language related plans towards IE, RP and $\mathrm{AE}$, their awareness of IE as a dialect, and their description of stereotypical IE features, to understand the local perspective (Bonnici \& Chand 2008, V. Chand 2008).

Importantly, separate from the call center and English improvement education industry, these individual IE speakers are also aware of the merger as a feature of IE, and not as a feature of standard English dialects:

I am quite aware of it when I speak to somebody who is so-called native speaker of English, so a Britisher, an American, a Canadian, an Australian ... If I am sitting with a bunch of ten Indian friends I'd probably be making my W's ...V's. (m35MS, 3:43-4:5)

While m35MS references the merger, more common are contrasts between sets of practices; the $\mathrm{v} / \mathrm{w}$ merger is understood by Indians as one practice within a set of local language practices. Interestingly, this speaker, like Azaria performing Apu's voice, has made the wrong folk hypothesis about the direction of the merger, ${ }^{7}$ while referencing the ideological link between IE and non-nativeness. The overt connection that m35MS draws between particular local language practices and more global assessments of nativeness reflect the first entailment in the IDEOLOGY OF NATIVENESS, but he disavows the ideology and instead dialogically challenges how native-speaker status is attributed only to inner-circle Englishes (Kachru 1986), by hedging their presumed exclusive English native status with "so-called." IE speakers are thus asserted to be ANOTHER native community.

Several speakers challenged global understandings of "neutral" as referencing an outside standard, while some even problematized the existence of any neutral dialect: 
There is this perception that, you know, if an Indian speaks English, and if an American speaks English, obviously there is this huge difference ... there's an Indian touch to it, and there is British or an American touch to it (f18MG, 22:37-39). People just kind of speak English in the way they're ... they're used to basically ... in America, people have their different accents because ... people around them have the same accent. And ... in the British way of speaking, I think it's like the similar way ... I don't think there's like a major - you know, as in, anything is sillier or harsh or anything. (f17AU, 18:19-24)

Their responses dialogically acknowledge and challenge global standard language ideologies regarding the ideological construction of a "neutral" accent. f18MG suggests that while there are differences across dialects, each has a "touch," while f17AU believes that accents need to be framed within localized community norms and cannot be qualitatively evaluated outside their respective local contexts.

Concurrently existing is discourse accepting a neutral accent, but IE is now located as "neutral" or "accentless" in a global context. This discourse directly challenges call center institutional ideologies, which are attempting to make IE "neutral" through prescriptive training courses. As well, it clearly demonstrates how the ideology of nativeness can be instantiated from a localized reference point: The ideology is not uniformly (re)articulated across the globe as always framing AE or RP as "neutral" and "standard":

(2)

VC: And where would you rank Indian English?

SB: I think its one of the best. No doubt.

VC: Yeah.

SB: Yeah. It's, I think many people love our Indian English, if I am not mistaken. The American also they get very pleased with our because there is no accent, we just, we talk the way we are...American is fun no doubt, but Indian is just very simple.

VC: Um-hum.

SB: There is no added tone or whatever. (f28SB, 32:45-33:7, emphasis mine)

As well, AE is specifically highlighted as the "other" and divergent from "neutral" IE:

(3)

SS: Delhi English is normal, simple Delhi English. Like maybe like what I'm speaking, I don't think there's any accent in what I'm - in my vocabulary, no. It's like that only. They don't have any twang or any accent or anything like that. It's just a normal, plain, simple English.

VC: So then -

SS: $\underline{I}$ think that is better.

VC: Better in what way?

SS: More simpler to understand. More simpler to speak. (f60SS 12:44-13:6, emphasis mine)

The "twang" of AE is referenced often in descriptions of AE by IE speakers. More broadly, such discourse serves to remove an AE accent from local understandings of neutral or standard English. 
IE is also interpreted as "more liberal," wherein a single local standard does not exist:

(4)

PG: I think Indian English is far more open. It's a little bit more open. It's a little bit more, it's balanced.

VC: How so?

PG: Um, well, it's got a mix of both, like okay for instance a word like colleague. I can even pronounce it as 'colleague' [ka.lig]. I can even pronounce it 'colleague' [ka.lig̊]. You know what I am saying, so there is that much more flexibility whereas if I am a Britisher or if I'm in London, I'd probably be looked down upon if I'm pronouncing a particular word in a particular manner because the British, the Europeans are very particular about, especially the British are very particular about how they pronounce things, so in that sense I think it's a little bit more liberal. It's a little bit more open as compared to others. American English, it's a little difficult to understand especially when somebody's talking in a very - in a very fluent manner, so for a normal average person it might get, he might take a minute a grapple with, okay what did he say, just repeat your sentence, dude that kind of thing.

VC: Um-hum.

PG: So that's why I find Indian English has a right mix of both. (f30PG, 20:15-30, emphasis mine)

f30PG dialogically references global and British processes of language evaluation, suggesting that such processes are not a factor in local Indian ideological constructions of speakerhood value. IE is valorized as placing less, if any, emphasis on prescriptive notions of correctness - here realized in different realizations of word stress - and is also globally situated as being a context in which speakers can draw on different globally available linguistic resources. As well, we find that AE is framed as unintelligible, in contrast to neutral IE. Shuck's (2004) ideological entailments are evident, but reframed in the local context to scrutinize nonlocal Englishes.

Not all speakers disavow prescriptive notions of correctness, and an idealized English; however, globalized standard and native language ideologies are again dialogically challenged. A common theme from older IE speakers - born preIndependence - is that English is spoken most "correctly" in India, and not in inner-circle "standard" language contexts:

I think India by far has the best command of the language, the people who have, who are educated. Even better than English people. I can't say what will happen ten years from now because, in India, English language was taught with more emphasis on the grammar. Then on the spoken English, in the initial years. That is why, you will find that the spoken English in India is grammatically more correct than anywhere else in the world. (m64NS, 20:16-20)

m64NS correlates "correct" and "better" English specifically with IE, given India's history of prescriptive English grammar training. He uses the rigor of English grammatical training in Indian schools as a means of evaluating the relative value of different English dialects. The global ideology is reworked and locally 
framed, offering a different commodification of global social value by relocating the standard. As well, this discourse does not speak to nativeness; if "correct" English can be acquired through grammar training, then nativeness loses relevance as a means of distinguishing speakers, and hence as a means of assessing relative global social authority. The first entailment of Shuck's (2004) ideology is not just missing, but disavowed.

However, while older IE speakers confidently locate IE as globally neutral and as a model for correct English, younger IE speakers are less confident in their own English skills:

At college ... we're considered snobs because we speak supposedly good English, which I don't agree with, because I find myself mispronouncing so many words. (f18ND, 17:37-40) ${ }^{8}$

Youths directly question their own fluency and nativity, indexing globalized ideologies about nativity and standard language; they are more influenced by global language ideologies than older generations. Further, they correlate "good" English with snobbery, locating it as foreign: Using "good" English is snubbing the local norm, IE.

These younger IE speakers, whose voices we heard above, several of them expressing doubt as to their English meeting the target, are English/Hindi bilinguals. Their entire education, through college, has been English-medium; they use English in intimate domains and with all technology (texting, e-mail, Internet, etc.); and their self-professed dominant language is English. And yet they are uncertain of how well their English meets external, global standards. This insecurity is a direct result of the disparate power relationship between inner-circle nations and third-world postcolonial outsourcing nations like India, where standard language ideologies directly affect individual and societal notions of fluency, competence, and nativeness.

However, these youths also dialogically acknowledge that international normalized language practices, and their associated social authority, are not available for local uptake. They critically respond to local speakers who quickly acquire international language practices, akin to the "cultural cringe" toward American language practices found in New Zealand (Meyerhoff \& Niedzielski 2003). In India, discourse centers on "fake accents," which typically emerge in high-school and college-age IE speakers who unnaturally acquire an American accent through limited contact with AE speakers or travel to the United States. These youths all had personal favorite stories highlighting the ridiculousness of fake accents and their response to such "wannabes," some of which I share here.

(5)

VC: When you were in school or in college, did you ever see anybody having a fake accent? Like -

RG:Yeah.@@ 
RG: @@ There are all kinds of people. Okay. I had this - I knew someone in my college, when I was doing my bachelor's in Hindu College...This woman, she went to the airport and back to drop someone or receive someone, and she came back with an accent. Someone who went to America for a three-week-long vacation came back with an accent. So there were all sorts. @ And I've had friends who've been there for so long who don't have an accent. So I think it's, again, got to do with, you know, how cool you think you are and emulating the West, like we've always done.

VC: And do people ever have like a British accent, or is it always American?

RG: American, surprisingly, yeah. (f27RG, 12:33-13:5, emphasis mine)

Further, they reject and denigrate such practices:

(6)

AU: Obviously you can't really, you know, kind of just go up to a person and say, 'You have a fake accent,' but, you know, behind their backs, they obviously, you know, kind of go like, you know, 'This girl, she has a fake accent, and, you know, she's such a wannabe,' this and that. That's - basically, they just talk. Nothing really, as in, they don't -

VC: So they wanna be - what do they wanna be? I mean, do they wanna just be American or -

AU: I don't know. That's what I don't get, as in, you know, if you're like an Indian, you should be, you know, kind of proud to be an Indian. (f17AU, 19:31-38, emphasis mine)

They even actively call others on their speedy acquisition of an American accent:

ND: And behind their backs, you can make fun of them, but some people are so direct, they'll just be like, 'You didn't have an accent before. What happened to you? You just went to the U.S. for two months on holiday.'

VC: @@@So-

ND: And it's like, 'Oh, yeah, I have got cousins there, actually.' And you're like, 'Oh, that's not a very good excuse'.... you can be a social embarrassment if you do that. We will embarrass you.

VC: So do people - do they try it and then they knock it off, or do they keep it up?

ND: Some people, it's very genuine. I mean, some people who've lived abroad, you know, they can't help it. But other people here, we make fun of them and they stop after some time. They deny it, but then they stop. (f18ND, 16:2-18, emphasis mine)

These stories and reactions tell us several things. First, they demonstrate an awareness that language practices are not something one can change with the season; they reflect one's history and background (e.g., "some people who've lived abroad ...they can't help it (their AE accent)"). ${ }^{9}$ This in itself challenges globalized language ideologies by explaining language variation through the socio-historical milieu in which local language practices emerge and are learned. Second, the fact that all the "fake accent" stories related to me involved the (improper) acquisition of an AMERICAN accent speaks to the power and global social authority of the United States, and American accents, demonstrating that local IE speakers are aware of such global commodification. Third, that fake accents are both regularly acquired and challenged ${ }^{10}$ speaks to the ongoing negotiation of local and global social authority that accompanies language practices in global circulation. 
We cannot talk about globalization and localization as sequential, nor simply as simultaneous; they are constantly renegotiated, and hence must be understood as symbiotic and syncretic. The fake accent phenomenon has become a social reality for these IE speakers, and discourse about fake accents is then used to challenge global(ized) ideologies about nativeness, about language acquisition, and about differences in local and global authenticity and social authority. Finally, fake accent discourse illuminates IE's local social value. ${ }^{11}$ Youths who use fake accents are interpreted as being embarrassed by their heritage and nation, and IE is taken up as a symbol of national pride and linguistic confidence. This ideological construction of IE as locally authentic and as a valuable local social commodity further challenges globally imposed language ideologies and assessments of social authority.

These locally valorizing ideologies are also evoked in other forms, for example in reaction to the language and cultural training imposed by the call center industry. While those entering the workforce circa 1995 and after increasingly have extra disposable income and an eye for Western products and styles - "We are no less conventional than we were five years ago, but, more and more, we splurge on imported cosmetics, Western brands and international foods" (Rai 2005) - they are not reconciled to global evaluations which stigmatize IE, as a call center employee demonstrates: "The job is so false ... [y]ou talk like an American, behave like one, but you are not one. It's almost like a trap" (Basu 2004); while successful at "crossing," they do not feel authentic in this identity. The focused backlash against AE uncovered in fake accent discourse must be understood within the context of the call center industry: Local stereotypes of Americans are complex and often negative, and the local value of AE is similarly downgraded, as compared to its global value. While American products and media are valued, other aspects of America are not, including American people (e.g., "The way the Indian call center worker has been the source of ridicule in the U.S., the angry American caller has become legend in India"; Kennedy 2007), American cultural practices ("It would be wrong to say, if I use the word American culture, American has no culture ... because apparently what looks glossy is not always good"; m64NS 10: 38-40), and American morals ("Everyone is like, 'Oh, Bush. Oh, yeah.' I mean ... women are not allowed to ... have the like abortion, but ... killing Iraqis is, 'Oh, that's not massacre, but abortion is",; f18ND 17:37-39). The presumed global social authority connected to Americans is not simply transferred to the local Indian setting; instead, these pejorative reflections circulating in local discourse affect how global ideologies are negotiated and ultimately not accepted in the local setting.

As well, there is evidence that the entailment of IE as indexing national or cultural pride is rooted in local reactions to call center operators, who work unorthodox hours and are encouraged to understand, if not adopt, American cultural practices:

We had people lying about working in a call center. We had women being looked at suspiciously by their neighbors because they'd leave in the night and come back in the morning. One of the girls was saying that, 'In my society they 
used to say, "Oh, there goes the call girl. The call center girl." In real life, call center workers are often accused of rejecting 'Indian family values' for a frivolous, consumerist lifestyle. (Kennedy 2007)

Call center workers are economically valued but culturally stigmatized in India, and their language practices are similarly scorned: The local sociolinguistic ideologies reflect a negotiation between local and global ideologies and attributed social value. Recognizing that global social authority is not available through the overly rapid acquisition of commodified AE language practices encourages a local (re)assessment of IE, in which, the v/w merger is situated, as authentic and locally valuable.

Importantly, many call center employees are non-native English speakers from lower and lower-middle class backgrounds; they are "different from the other members of the English-using elite(s)" (Rahman 2009). The ideologies reified through call center interactions are, however, applied to ALL Indians. These native IE speakers whose voices we heard above, none of whom has direct experience as a call center worker, must still deal with these global ideologies framing them as non-native. Through their attitudes and reflections on English(es), we find that they are dialogically reacting to these national-level, globally imposed assessments.

D I S C U S S I O N

These individual reflections on IE, and English fluency, competence, and ownership are not easily reconciled, nor should we attempt to portray them as unified. They do, however, stand in contrast to the ideological uniformity of AE speakers' assessments of IE, reflecting global(ized) language ideologies. In this sense, this analysis demonstrates that $\mathrm{AE}$ speakers are interacting and evaluating on a global scale, while IE speakers are dialogically responding and contributing to both global and local ideologies. I suggest that this pattern will hold in other contexts: Those with hegemonic social authority only speak from and to global ideologies, reifying global belief structures, while less valued global participants are more inclined to interact dialogically with, challenge, and negotiate the differences between local and global institutional(ized) ideologies. These IE speakers offer a much more nuanced understanding of how IE can be both locally valuable and globally stigmatized, and they also refrain from pigeonholing speakers from different dialects as completely as the AE speakers do, in terms of personality, aptitude, and employment, instead occasionally describing other dialects in terms of actual linguistic features, such as AE's "twang."

The conscious choice to speak dialogically to competing ideologies reflects an investment in perpetuating or discontinuing global language ideologies. Within this, AE speakers - torchbearers of standard language - are invested in continuing their global preeminence, while IE speakers, torchbearers of a nonstandard variety, have garnered negative international media attention and can gain global social authority through their contestation of global language ideologies. Meanwhile, 
the unconscious choice of whether one responds to competing ideologies may reflect differences in awareness of these competing ideologies; while various news sources present similar IE reflections, they are not yet being acknowledged in institutional contexts. AE reflections thus must be interpreted both in terms of their awareness of standard language ideologies, and in terms of their potential unawareness of competing discourse. Within a Sociolinguistics of Globalization, we must remain cognizant that while certain discourses are globally circulated, others remain locally bound. Our examinations of how global and local processes interact will need to attend to such divergences.

C O N C L U S I O N

This examination has uncovered societal ideologies in the U.S. context that disparage the IE accent for its purported unintelligibility, and examples of how these ideologies become enacted or embodied pejoratively as social beliefs about IE speakers. As well, we have seen how AE notions of correct English directly target the IE v/w phenomenon, via U.S.-based accent reduction courses and media caricatures. Similarly, on the IE side, we have seen that IE speakers are aware of the v/w phenomenon, and that global standard language ideologies affect IE self-evaluations of English fluency and competency. These are internalized, but also contested in that AE is not seen as "the standard," but instead, either some intangible, grammar-based version of English or IE is idealized as "neutral." The sociolinguistic realities and ideologies are enmeshed, and they interact to promote an idealized "neutral" English as the local target, while globally the ideology of nativeness frames AE as "standard," and deviations from this standard are treated as other, non-native, and wrong.

\section{N O T E S}

${ }^{1}$ I am grateful to the editor and two anonymous reviewers for their helpful comments and criticisms on earlier drafts of this article, and to Janet S. Shibamoto Smith and Orhan Orgun for their guidance and advice. This research was supported by a Wenner-Gren Foundation for Anthropological Research dissertation fieldwork grant (\#7702) and a National Science Foundation Linguistics Program dissertation improvement grant (\#0819246). Aspects of this article were presented at the 14th Conference of the International Association of World Englishes at the City University of Hong Kong, 5 December 2008, and the 26th South Asian Language Analysis Conference at the Central Institute of Indian Languages, Mysore, 20 December 2006, and the 35th New Ways of Analyzing Variation Conference at Ohio State University, Columbus, 10 November 2006.

${ }^{2}$ Acoustic and variationist research on Delhi IE has shown that there is not a complete merger of $/ \mathrm{v} /$ and /w/ (V. Chand 2007, Trudgill \& Hannah 2002). No speaker completely merges the two phonemes, and speakers are variable in how frequently they pronounce [w] for $/ \mathrm{v} /$. While folk analyses by both IE and non-IE speakers suggest that $/ \mathrm{w} /$ is pronounced as [v], linguistic analysis has demonstrated the opposite: $/ \mathrm{v} /$ is often realized as an approximant. The title of this article references this folk analysis.

${ }^{3}$ Although I have excluded South Indians from this study, it is important to consider stereotypes about them in this section because a number of popular conceptions of Indian speech in America are based on South Indian speech. 
${ }^{4}$ Half of the words were presented in isolation, and half were presented within contextualized sentential frames.

${ }^{5}$ The first sample group was presented with AE input first (hereafter the AEfirst group), while the second sample group was presented with the same input, but in reversed order (hereafter the IEfirst group). Each response is coded for the sample group and the respondent code (e.g., R1). Within their responses the participants referenced Speaker A and B or 1 and 2, depending on which sample they were in; I have added which speaker they intend, based on their input order, with [IE] or [AE] to make clear which input they were referencing. All the original grammatical and spelling errors within the responses have been left in.

${ }^{6}$ In the transcribed extracts, I use normal orthography and punctuation whenever possible, for readability. When phonetic transcription is necessary to capture relevant details, I use IPA, enclosed in brackets [], and boldface to highlight primary syllable stress. Ellipses (...) are used in the traditional manner and replace extraneous speech not directly relevant to the topic under discussion. @ indicates laughter, with one character per syllable of laughter. Hyphens (-) indicate interruptions or incomplete utterances. Parentheses () are used to contextualize generic pronouns like $i t$, based on the surrounding discourse. Speakers are identified by their initials, and VC is my speech, as the interviewer. Participants are designated in a semi-anonymous fashion, and their gender and age are presented: f18AD, for example, is an 18-year-old female. The quotes are cited based on their location within the transcripts, e.g. (f60SS 12:44-13:6) is from f60SS's interview, page 12 line 44 through page 13 line 6 . Underlined portions of the quotes are used to emphasize their relevance to my arguments.

${ }^{7}$ This folk hypothesis may in fact be a structural hypercorrection.

${ }^{8}$ This English proficiency comes at a cost, of course. Both younger and older IE speakers are worried that increased English use - across domains - by the younger generation is related to a loss of culture, and a loss of Indian identity.

${ }^{9}$ These are also reflected in Pakistan: Accent malleability is challenged by Pakistani call center employees, and their reactions are similarly negative toward AE-accented speakers who did not legitimately acquire their accent through extended time in the United States (Rahman 2009).

${ }^{10}$ Speakers (17-35) related fake accent stories from college and high school experiences.

${ }^{11}$ Interestingly, Pakistani English holds local value and "phony accents" (Rahman 2009) are discouraged, but Pakistani English is also denigrated: "There is cultural shame about Pakistani English including the very term itself" (Rahman 2009).

$$
\text { R E F E R E N C E S }
$$

Abbi, Anvita (1980). A semantic grammar of Hindi: A study of reduplication. New Delhi: Bahri.

Accent Reduction Institute (2008). Accent Reduction Institute website Main page, http://www. lessaccent.com/

Agnihotri, Rama Kant, and Sahgal, Anju (1985). Is Indian English retroflexed and r-full? Indian Journal of Applied Linguistics 11:97-109.

Azaria, Hank (2004). Interview with Terry Gross. Fresh Air, WHYY Philadelphia: National Public Radio. http://www.npr.org/templates/story/story.php?storyId=4679119

Bakhtin, Mikhail M. (1981). The dialogic imagination. Austin: University of Texas Press.

Basu, Indrajit (2004). The faces of globalization: A dilemma for India. Calcutta: United Press International.

Baumgardner Robert J. (ed.) (1996). South Asian English: Structure, use and users. Urbana: University of Illinois Press.

Blackburn, Mollie V. (2005). Agency in borderland discourses: Examining language use in a community center with black queer youth. Teachers College Record 107:89-113.

Blommaert, Jan (2003). Commentary: A sociolinguistics of globalization. Journal of Sociolinguistics 7:607-23. 


\section{LOCAL AND GLOBAL IDEOLOGIES ABOUT INDIAN ENGLISH}

Bonnici, Lisa, \& Chand, Vineeta (2008). The impact of colonial history and multilingualism on dialect formation: Contrasting Malta and India. Paper presented at New Ways of Analyzing Variation Conference (NWAV-37), Houston, Texas.

Bourdieu, Pierre (1991). Language and symbolic power. Cambridge, UK: Polity Press.

Chand, Tara (1944). The problem of a common language for India. In Tara Chand (ed.), The problem of Hindustani, 13-40. Allahabad: Indian Periodicals.

Chand, Vineeta (2007). Phonemes, graphemes and mutual intelligibility: Dialectal variation in [v] and [w]. Ms., Department of Linguistics, University of California, Davis.

(2008). Hinglish identity: Changes in language practices and attitudes in urban India. Paper presented at 14th Conference of the International Association for World Englishes, City University of Hong Kong.

(2009). Political, Social and Linguistic Dimensions of Urban Indian English Language Practices. Dissertation, University of California, Davis.

— (in preparation). Postvocalic (r) in urban Indian English. Submitted to English World-Wide.

Chaturvedi, M.G. (1973). A contrastive study of Hindi-English phonology. Delhi: National Publishing House.

Chelliah, Shobhana L. (2006). The representation of Indian English in Indian English novels. Paper presented at South Asian Languages Analysis 26 (SALA), Kannada University \& Central Institute of Indian Studies, Mysore.

Coelho, Gail M. (1997). Anglo-Indian English: A nativized variety of Indian English. Language in Society 26:561-89.

Coupland, Nikolas, \& Bishop, Hywel (2007). Ideologised values for British accents. Journal of Sociolinguistics 11:74-93.

Cowie, Claire (2007). The accents of outsourcing: The meanings of "neutral" in the Indian call centre industry. World Englishes 26:316-30.

Dendrinos, Bessie; Karavanta, Mina; \& Mitsikopoulou, Bessie (2008). Introduction: Theorizing New English(es). European Journal of English Studies 12:1-14.

Dudley, Brier (2004). Microsoft's call-center business in India gets an American accent. Seattle Times. http://seattletimes.nwsource.com/html/microsoft/2002006164_indiaenglish16.html

Emeneau, Murray B. (1980[1956]). India as a linguistic area. In Anwar S. Dil (ed.), Language and linguistic area: Essays by Murray B. Emeneau. Stanford: Stanford University Press.

Erling, Elizabeth J (2007). Local identities, global connections: Affinities to English among students at the Freie Universität Berlin. World Englishes 26:111-30.

Fairclough, Norman (2006). Language and globalization. London: Routledge.

Gal, Susan, and Irvine, Judith T. (1995). The boundaries of languages and disciplines: How ideologies construct difference. Social Research 62:967-1001.

Gordon, James, \& Gupta, Poonam (2004). Understanding India's services revolution. New Delhi: International Monetary Fund Working Papers. http://imf.org/external/pubs/ft/wp/2004/wp04171.pdf

Gorman, Anna (2007). Accentuating the "American" in their speech. Los Angeles Times. http://www. amren.com/mtnews/archives/2007/10/accentuating_th.php

Heller, Monica (2003). Globalization, the new economy, and the commodification of language and identity. Journal of Sociolinguistics 7:473-92.

John, Binoo K. (2007). Entry from backside only: Hazaar fundas of Indian-English. New Delhi: Penguin.

Joseph, Manu (2002). Say hello to Sanjeep, er, Sam. Wired. http://www.wired.com/techbiz/media/new $\mathrm{s} / 2002 / 10 / 55799$

Kachru, Braj B. (1982). South Asian English. In R. W. Bailey and M. Gorlach (eds.), English as a world language. 353-83. Ann Arbor: University of Michigan Press.

(1983). The Indianization of English. Oxford: Oxford University Press.

(1986). The alchemy of English: The spread, functions and models of non-native Englishes. Oxford: Pergamon. 
Kennedy, Miranda (2007). India calling. American Public Media, http://marketplace.publicradio.org/ display/web/2007/04/13/india_calling/

Krishnaswamy, N., \& Burde, Archana S. (1998). The politics of Indians' English: Linguistic colonialism and the expanding English empire. Delhi: Oxford University Press.

Labru, G. L. (1984). Indian newspaper English. Delhi: B.R. Publishing.

Lee, Jamie Shinhee (2006). Linguistic constructions of modernity: English mixing in Korean television commercials. Language in Society 35:59-91.

Lee, Jeanne (2008). Simpsons-o-rama sounds. http://www.angelfire.com/il/simpsonsfun/sounds.html\#apu

Lippi-Green, Rosina (1997). English with an accent: Language, ideology, and discrimination in the United States. London: Routledge.

Machin, David, \& van Leeuwen, Theo (2003). Global schemas and local discourses in Cosmopolitan. Journal of Sociolinguistics 7:493-512.

Mahapatra, Rajesh (2006). IBM's technology to boost English skills at call centers. India-West B5, November 3, 2006.

Malkani, Gautam (2006). Londonstani. London: Fourth Estate.

McPhate, Mike (2005). Outsourcing outrage: Indian call-center workers suffer abuse. San Francisco Chronicle, November 17, 2005. http://www.sfgate.com/cgi-bin/article.cgi?f=/c/a/2005/11/17/BUG B3FPGT01.DTL\&type=tech

Meyerhoff, Miriam, \& Niedzielski, Nancy (2003). The globalisation of vernacular variation. Journal of Sociolinguistics 7:534-55.

Migration Dialogue (2005). India: Remittances, high-tech. Migration News Online. http://migration.u cdavis.edu/mn/more.php?id=3104_0_3_0

Milroy, James (2001). Language ideologies and the consequences of standardization. Journal of Sociolinguistics 5:530-55.

Milroy, Lesley (2000). Britain and the United States: Two nations divided by the same language (and different language ideologies). Journal of Linguistic Anthropology 10:56-89.

Nichols, John (2004). Voters in India say no to globalization. Madison Capital Times, May 18, 2004. http://www.commondreams.org/views04/0518-08.htm

Pennycook, Alastair (2007). Global Englishes and transcultural flows. London: Routledge.

Rahman, Tariq (2009). Language ideology, identity and the commodification of language in the call centers of Pakistan. Language in Society 38.

Rai, Saritha (2005). India's boom spreads to smaller cities. The New York Times http://www.nytimes. com/2005/01/04/business/worldbusiness/04yum.html?_r=1\&scp=1\&sq=India\%92s\%20boom\%20 spreads $\% 20$ to $\% 20$ smaller $\% 20$ cities \&st=cse.

Raj, Dhooleka S. (2003). Where are you from? Middle-class migrants in the modern world. Berkeley: University of California Press.

Rampton, Ben (1995). Crossing: Language and ethnicity among adolescents. London: Longman.

- (1999). Crossing. Journal of Linguistic Anthropology 9:54-56.

Sahgal, Anju (1991). Patterns of language use in a bilingual setting in India. In Jenny Cheshire (ed.), English around the world: Sociolinguistic perspectives. Cambridge: Cambridge University Press.

— \& Agnihotri, Rama Kant (1988). Indian English phonology: A sociolinguistic perspective. English World-Wide 9:51-64.

Shankar, Shalini (2004). Reel to real: Desi teens' linguistic engagement with Bollywood. Pragmatics 14:317-35.

Shohamy, Elana (2007). Reinterpreting globalization in multilingual contexts. International Multilingual Research Journal 1:127-33.

Shuck, Gail (2004). Conversational performance and the poetic construction of an ideology. Language in Society 33:195-222. 


\section{LOCAL AND GLOBAL IDEOLOGIES ABOUT INDIAN ENGLISH}

Silverstein, Michael (1996). Monoglot "standard" in America: Standardization and metaphors of linguistic hegemony. In Donald Brenneis \& Ronald K.S. Macaulay (eds.), The matrix of language, 284-306. Boulder: Westview.

Tharoor, Shashi (2007). The elephant, the tiger, \& the cell phone: India, the emerging 21st-century power. New York: Arcade.

Thurlow, Crispin, \& Jaworski, Adam (2003). Communicating a global reach: Inflight magazines as a globalizing genre in tourism. Journal of Sociolinguistics 7:579-606.

Trudgill, Peter, \& Hannah, Jean (2002). International English: A guide to varieties of Standard English. New York: Oxford University Press.

-, Schreier, Daniel; Long, Daniel; \& Williams, Jeffrey P. (2004). On the reversibility of mergers: /W/, /V/ and evidence from lesser-known Englishes. Folia Linguistica Historica 24:23-45.

Tucker International (2004). English language and American culture: A full-service international human resource development company. http://www.tuckerintl.com//callcntr_prog/indian_callcntr_detail.html

Vaid, D.D. (1977). Improve your English. Delhi: Orient.

(1982). How to speak \& write better English. Delhi: Orient.

Wassink, Alicia Beckford, \& Curzan, Anne (2004). Addressing ideologies around African American English. Journal of English Linguistics 32:171-85.

Woolard, Kathryn A. (1998). Language ideology as a field of inquiry. In Bambi Schieffelin, Kathryn A. Woolard \& Paul Kroskrity (eds.), Language ideologies: Practice and theory, 3-47. New York: Oxford University Press.

World Bank (2006). Purchasing power parity: GDP. Washington, DC: World Bank Group. http://site resources.worldbank.org/DATASTATISTICS/Resources/GDP_PPP.pdf

(Received 21 April 2008; revision received 28 February 2009; accepted 28 February 2009; final revision received 28 February 2009) 